\title{
Near-ridge-axis volcanism affected by hotspot: insights from effective elastic thickness and topography of the Ojin Rise Seamounts, east of Shatsky Rise in the northwest Pacific Ocean
}

\author{
Shoka Shimizu ${ }^{1 *}$, Masao Nakanishi ${ }^{2}$ and Takashi Sano ${ }^{3}$
}

\begin{abstract}
We used recently collected bathymetric data and published gravity data to examine the effective elastic thickness of the lithosphere and the crustal thickness beneath the Ojin Rise Seamounts, located east of Shatsky Rise in the northwest Pacific Ocean. An admittance analysis of the bathymetric and gravity data indicates that the effective elastic thickness of the Pacific plate under the Ojin Rise Seamounts is $2.7 \pm 0.1 \mathrm{~km}$, implying that the seamounts were formed on or near the spreading ridge between the Pacific and Farallon plates. The mean crustal thickness beneath the seamounts estimated from the mantle Bouguer anomaly is $10.1 \pm 1.7 \mathrm{~km}$, which is thicker than the surrounding crust. The thick crust was probably formed by the interaction between the Pacific-Farallon ridge and a hotspot forming Shatsky Rise. Our results indicate that late-stage volcanism after the formation of the main edifices of Shatsky Rise spread widely beyond the eastern side of the rise, forming the Ojin Rise Seamounts.
\end{abstract}

Keywords: Effective elastic thickness, Ojin Rise Seamounts, Shatsky Rise

\section{Introduction}

The formation of oceanic plateaus is an important unresolved problem in Earth science. Oceanic plateaus are thought to be emplaced by rapid, voluminous eruptions over a surfacing mantle plume head (e.g., Duncan and Richards 1991). However, secondary (late-stage or postplateau) volcanism also plays an important role in the formation of oceanic plateaus (e.g., Ito and Clift 1998; Pietsch and Uenzelmann-Neben 2015). Late-stage volcanism includes volcanism along the hotspot track and rejuvenated-stage volcanism. According to the plume model, hotspot-track volcanism represents activity of

\footnotetext{
*Correspondence: aaxa2108@chiba-u.jp

${ }^{1}$ Graduate School of Science and Engineering, Chiba University,

Chiba 2638522, Japan

Full list of author information is available at the end of the article
}

the plume tail (e.g., Hawaiian-Emperor volcanic chain; Clague and Dalrymple 1987). Rejuvenated-stage volcanism may occur as a result of melting of lithospheric mantle beneath the plateau (e.g., Tejada et al. 2015). Latestage volcanism produced volcanic cones on the Manihiki Plateau (Pietsch and Uenzelmann-Neben 2015) and may have thickened the crust of the Ontong Java Plateau (Ito and Clift 1998). Thus, a comprehensive understanding of the formation of oceanic plateaus requires adequate knowledge of late-stage volcanism.

Shatsky Rise is proposed to have formed by the emergence of a mantle plume head at the ridge-ridge-ridge triple junction among the Pacific, Izanagi, and Farallon plates (Nakanishi et al. 1999). It consists of three major volcanic edifices, the Tamu, Ori, and Shirshov massifs, and the bathymetric high of Papanin Ridge (Fig. 1a). Drilled samples have yielded radiometric dates 

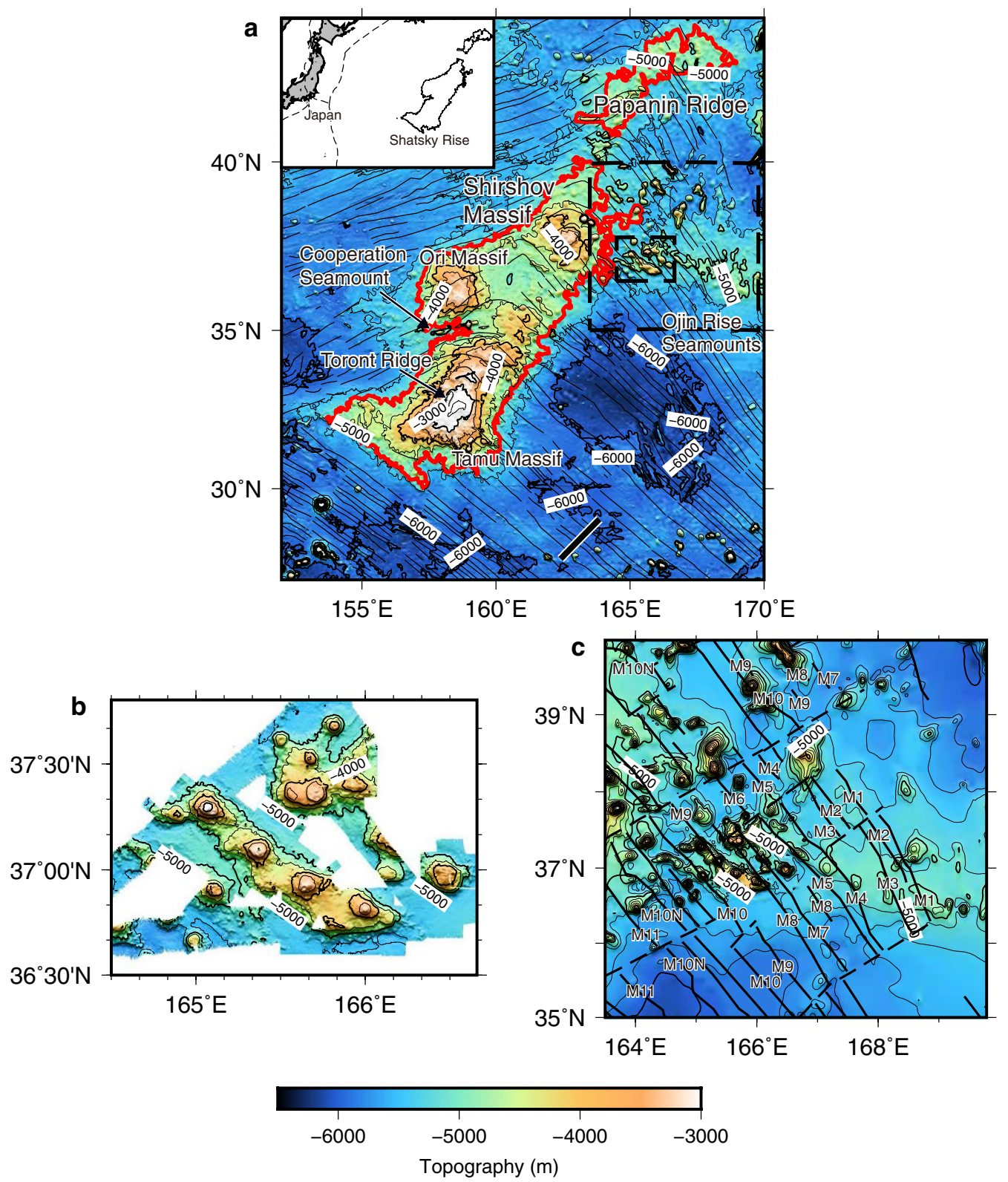

Fig. 1 Bathymetry of the study area. a Bathymetric map around the Ojin Rise Seamounts and Shatsky Rise. Bathymetric data are from Smith and Sandwell (1997); contour interval is $500 \mathrm{~m}$. Shatsky Rise is outlined in red at the $5000 \mathrm{~m}$ bathymetric contour. Thin black lines represent magnetic anomaly lineations (Nakanishi et al. 1999). The white-edged black line at lower center is the seismic reflection survey line of Ohira et al. (2017). The two dashed rectangles are the areas shown in $\mathbf{b}$ and $\mathbf{c}$. The inset shows the locations of Shatsky Rise, Japan, and present plate boundaries (dashed lines). b Bathymetric map based on data collected during cruise KR14-07. c Bathymetric map of the study area

of $\sim 145 \mathrm{Ma}$ for the Tamu Massif and $~ 134$ Ma for the Ori Massif (Mahoney et al. 2005; Geldmacher et al. 2014; Heaton and Koppers 2014). The maximum crustal thickness of the Tamu Massif is estimated to be $30 \mathrm{~km}$ on the basis of seismic refraction surveys (Korenaga and Sager 2012). Several studies have proposed that the thick crust of the massif was produced by deeper melting, with a higher degree of partial melting, than is typical at normal mid-ocean ridges (e.g., Sano et al. 2012). Previous studies have also suggested that late-stage volcanism occurred on Shatsky Rise (e.g., Sager et al. 2016; Shimizu et al. 2013; Tejada et al. 2016).

The Ojin Rise Seamounts (ORS) lies east of Shatsky Rise and consists of approximately 80 volcanic edifices. Torsvik et al. (2019) devised an absolute Late Jurassic-Cretaceous Pacific plate model and showed that the ORS is a 
hotspot track connected to Shatsky Rise. Nakanishi et al. (1999) speculated that part of the ORS (around $37^{\circ} 00^{\prime} \mathrm{N}$ and $165^{\circ} 30^{\prime} \mathrm{E}$ ) was formed near a spreading ridge because the elongation of the seamounts and the magnetic anomaly lineations have similar orientations (Fig. 1a). The crustal structure under the ORS is unknown. Tejada et al. (2016) indicated that the ORS was formed by late-stage volcanism related to the formation of Shatsky Rise and proposed two models of formation based on the geochemical data. One is that the ORS was formed by the interaction between volcanism of a spreading ridge and a hotspot. The other is that the ORS was formed only by deformation-related shallowmantle volcanism. Age information for the ORS is indispensable for testing these models.

The effective elastic thickness $\left(T_{\mathrm{e}}\right)$ value of the lithosphere under a seamount is an indicator of its tectonic setting (Watts 1978). The $T_{\mathrm{e}}$ value, the thickness of the lithosphere behaving as an elastic body, can be estimated from bathymetric and gravity data. The relationship between $T_{\mathrm{e}}$ and the age of the lithosphere at the time of loading was first proposed by Watts (1978). Small $T_{\mathrm{e}}$ values $(0-8 \mathrm{~km})$ suggest that the seamounts were formed on or near a spreading ridge. For example, $T_{\mathrm{e}}$ value of the lithosphere under the Foundation Seamounts near the Pacific-Antarctic Ridge is $0-5 \mathrm{~km}$, suggesting an age difference of 0-10 Myr between the seamounts and the lithosphere under them (Maia and Arkani-Hamed 2002), and $T_{\mathrm{e}}$ of the lithosphere under the Hawaiian Islands is $30-40 \mathrm{~km}$, indicating an age difference of 70-80 Myr between the islands and the adjacent seafloor (Watts 1978). In this study, we determined the crustal thickness and the $T_{\mathrm{e}}$ value of the lithosphere under the ORS to estimate its formation age, tectonic setting, and crustal structure.

\section{Theory and method}

We estimated the $T_{\mathrm{e}}$ value of the lithosphere under the ORS by an admittance analysis, a method of spectral analysis of the bathymetry and free-air gravity anomaly (FGA) in the wavenumber domain. We used the admittance function (McKenzie and Bowin 1976),

$$
Z(k)=\frac{C_{\mathrm{C}}(k)}{E_{\mathrm{t}}(k)},
$$

where $k$ is the wavenumber and $Z(k)$ is the gravitational admittance between the bathymetry and the FGA. $C_{\mathrm{C}}(k)$ is a cross spectrum of FGA and bathymetry, and $E_{\mathrm{t}}(k)$ is a power spectrum of bathymetry:

$$
\begin{aligned}
& C_{\mathrm{C}}(k)=\Delta g(k) H^{*}(k), \\
& E_{\mathrm{t}}(k)=H(k) H^{*}(k),
\end{aligned}
$$

where $\Delta g(k)$ and $H(k)$ are the Fourier transforms of the observed FGA and bathymetry, respectively, and the asterisk denotes the complex conjugate.

The $T_{\mathrm{e}}$ value can be estimated by comparing the admittance function of an elastic plate model with observational admittances (Watts 2001). The elastic plate model used in this study is one in which the load of a seamount is compensated by flexure of a plate. The admittance function of this model is defined by

$$
Z(k)=2 \pi G\left(\rho_{\mathrm{c}}-\rho_{\mathrm{w}}\right) \mathrm{e}^{-k d}\left(1-\Phi_{\mathrm{e}}(k) \mathrm{e}^{-k t}\right),
$$

where $d$ is the mean water depth, $G$ is the universal gravitational constant, $t$ is the mean crustal thickness, and $\rho_{\mathrm{w}}$ and $\rho_{\mathrm{c}}$ are the densities of seawater and crust, respectively. The flexural response function of the lithosphere $\Phi_{\mathrm{e}}(k)$ is (Walcott 1976)

$$
\Phi_{\mathrm{e}}(k)=\left[\frac{D k^{4}}{\left(\rho_{\mathrm{m}}-\rho_{\mathrm{w}}\right) g}+1\right]^{-1},
$$

where $g$ is the average gravitational acceleration, $\rho_{\mathrm{m}}$ is the density of the mantle, and $D$ is the flexural rigidity of the lithosphere defined by

$$
D=\frac{E T_{\mathrm{e}}^{3}}{12\left(1-v^{2}\right)},
$$

where $E$ is Young's modulus and $v$ is Poisson's ratio. These and other parameters used in this study are listed in Table 1.

The most suitable $T_{\mathrm{e}}$ value was determined by minimizing the root-mean-square (RMS) misfit between theoretical and observational admittances for various $T_{\mathrm{e}}$ values (Kalnins and Watts 2009; Hu et al. 2015). Kalnins and Watts (2009) noted that use of a very small spatial window $(\leq 400 \mathrm{~km})$ produces spuriously low $T_{\mathrm{e}}$ values by truncating the signals of features on stronger lithosphere. Our study area encompassing the ORS consisted of a $550 \mathrm{~km} \times 550 \mathrm{~km}$ window that did not include any major topographic features of the Shatsky Rise and Emperor Seamount Chain (Fig. $1 \mathrm{c} ; 35^{\circ} \mathrm{N}$ to $39^{\circ} 56.98^{\prime} \mathrm{N}$ and $163^{\circ}$ $30^{\prime} \mathrm{E}$ to $169^{\circ} 47.16^{\prime} \mathrm{E}$ ). We extended the grid by line symmetry to avoid the Gibbs phenomenon.

\section{Table 1 Parameters used in this study}

\begin{tabular}{lll}
\hline Parameter & Notation & Value \\
\hline Density of seawater & $\rho_{\mathrm{W}}$ & $1035 \mathrm{~kg} \mathrm{~m}^{-3}$ \\
Density of oceanic crust & $\rho_{\mathrm{c}}$ & $2836 \mathrm{~kg} \mathrm{~m}^{-3}$ \\
Density of sediment & $\rho_{\mathrm{s}}$ & $2100 \mathrm{~kg} \mathrm{~m}^{-3}$ \\
Density of mantle & $\rho_{\mathrm{m}}$ & $3300 \mathrm{~kg} \mathrm{~m}^{-3}$ \\
Young's modulus & $E$ & $0.7 \times 10^{11} \mathrm{~N} \mathrm{~m}^{-3}$ \\
Poisson's ratio & $v$ & 0.25 \\
\hline
\end{tabular}


The mean crustal thickness, which is required to calculate admittances with Eq. 4, can be estimated from the mantle Bouguer anomaly (MBA; Kuo and Forsyth 1988). The MBA can be calculated by subtracting the predicted attractions of the seawater-sediment, sediment-crust, and crust-mantle interfaces from the FGA under the assumption of a constant crustal thickness. When the crustal density is assumed to be constant, the MBA represents the spatial variation of crustal thickness, that is, undulations of the Moho. To calculate that spatial variation, we determined the constant reference crustal thickness for the ORS. To find a reasonable ORS reference crustal thickness, we calculated the crustal thickness within the area bounded by $27^{\circ} \mathrm{N}$ and $45^{\circ} \mathrm{N}$ and $152^{\circ} \mathrm{E}$ and $175^{\circ} \mathrm{E}$ (Fig. 1a), which is much larger than our study area. We chose the larger area because the crustal thickness in its southern part is known from a seismic reflection survey to range from 6.8 to $7.3 \mathrm{~km}$ (Ohira et al. 2017). We then calculated reference crustal thicknesses in steps of $0.1 \mathrm{~km}$ between 1 and $15 \mathrm{~km}$ and chose the value that minimized the RMS difference between the crustal thicknesses determined by Ohira et al. (2017) and our MBA calculation.

To determine the range of wavenumbers used to fit the observed and theoretical admittances, we used the coherence $\gamma^{2}(k)$, a measure of the portion of the FGA that is caused by bathymetry. McKenzie and Bowin (1976) defined coherence as

$$
\gamma^{2}(k)=\frac{C_{\mathrm{C}}(k) C_{\mathrm{C}}^{*}(k)}{E_{\Delta g}(k) E_{\mathrm{t}}(k)},
$$

where $E_{\Delta g}(k)$ is a power spectrum of the FGA. The coherence can range from 0 to 1 , and a high coherence indicates that most of the FGA is caused by bathymetry. Kalnins and Watts (2009) suggested that wavenumbers with coherence greater than a threshold value of 0.4 are suitable for admittance analysis, and we adopted that threshold for our admittance analysis.

\section{Bathymetric and gravity data}

Research cruise KR14-07 of R/V Kairei was carried out in summer 2014 to investigate the origin of the ORS and its relationship with Shatsky Rise (Sano 2014). Bathymetric data were collected using the vessel's SeaBeam 3012 multibeam echo sounder (Fig. 1b). Because the survey covered only a small fraction of the study area, we filled the gaps using gridded bathymetric data with a $1^{\prime} \times 1^{\prime}$ grid spacing made by Sager et al. (1999) using the splineunder-tension gridding algorithm of Smith and Wessel (1990), shown in Fig. 1c.

Because the coverage of shipboard gravity data by cruise KR14-07 and previous research cruises was insufficient for admittance analysis, we used the satellite-derived FGA gridded data of Sandwell et al. (2014), with a grid spacing of $1^{\prime} \times 1^{\prime}$ (Fig. 2). The sediment thickness was obtained from the gridded data of sediment thickness of Straume et al. (2019).

\section{Results}

The seamounts of the ORS, distributed within the area defined by latitude $36^{\circ} 30^{\prime} \mathrm{N}$ and $39^{\circ} \mathrm{N}$ and longitude $164^{\circ}$ $\mathrm{E}$ and $168^{\circ} \mathrm{E}$, are $\sim 1000-2000 \mathrm{~m}$ high and $\sim 10-20 \mathrm{~km}$ in diameter (Fig. 1c). An elongated ridge, parallel to Hawaiian magnetic lineations, is situated between $36^{\circ} 40^{\prime} \mathrm{N}$ and $37^{\circ} 20^{\prime} \mathrm{N}$ and $165^{\circ} \mathrm{E}$ and $166^{\circ} \mathrm{E}$ and is $126 \mathrm{~km}$ long, $67 \mathrm{~km}$ wide, and $1800 \mathrm{~m}$ high (Fig. 1b). Four seamounts on top of this ridge have diameters of $16-18 \mathrm{~km}$ and elevations of $\sim 800-1400 \mathrm{~m}$ above the ridge.

The FGA is positive over the seamounts of ORS, $\sim 30 \mathrm{mGal}$, and negative over the abyssal plain around the seamounts, less than $-20 \mathrm{mGal}$ (Fig. 2). The wavelengths of these gravity features are $\sim 20-30 \mathrm{~km}$.

The optimum reference crustal thickness determined from our MBA analysis is $8.5 \pm 0.1 \mathrm{~km}$; at this thickness the RMS difference between the result of Ohira et al. (2017; see Fig. 3c) and the best-fit crustal thickness reaches a minimum of $0.26 \mathrm{~km}$ (Fig. 3a). The crustal thickness variations along the survey line of Ohira et al. (2017) is shown with the best-fit crustal thickness

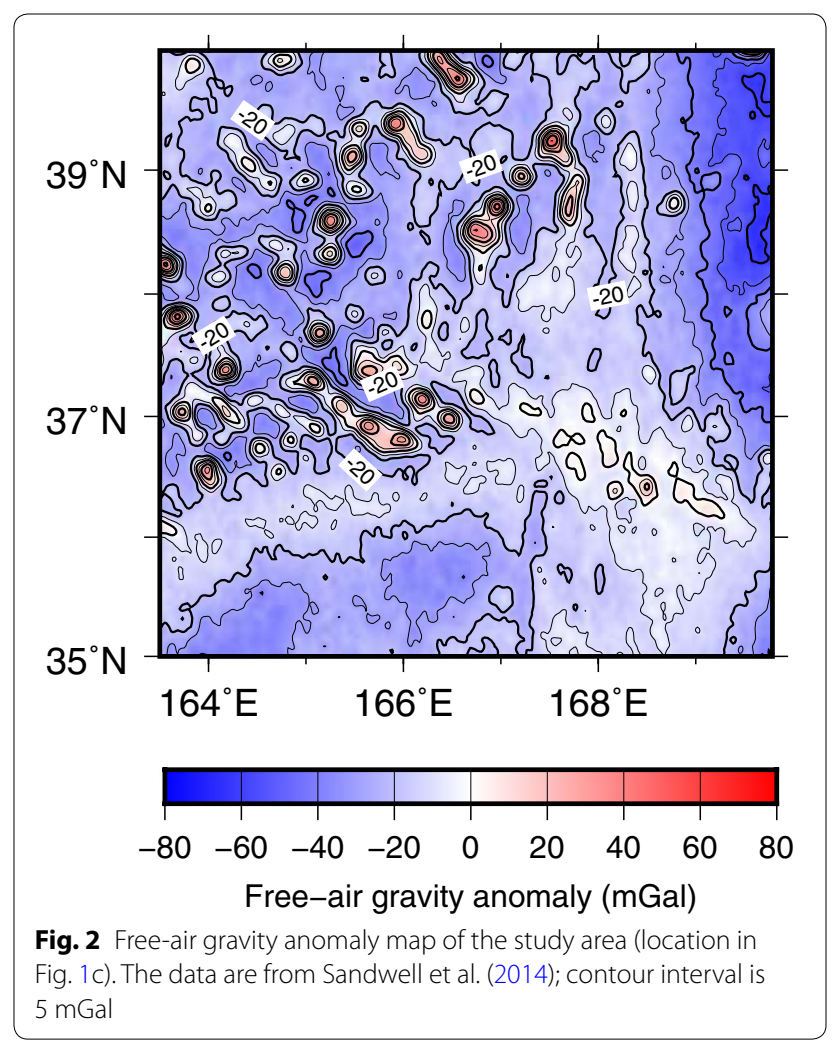




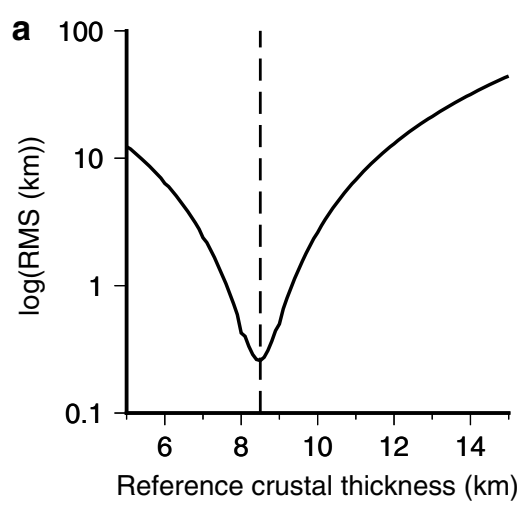

。

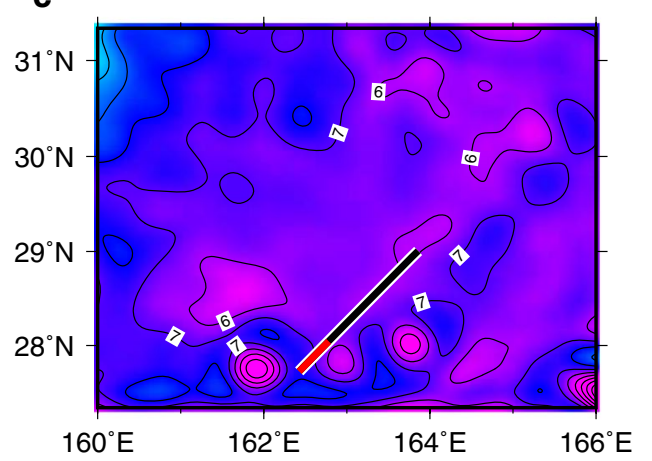

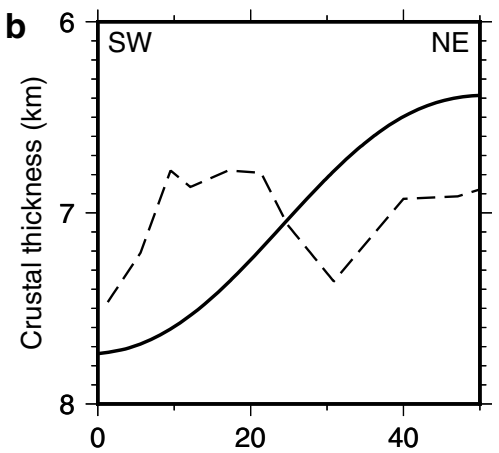

Distance from the starting point of the survey line $(\mathrm{km})$

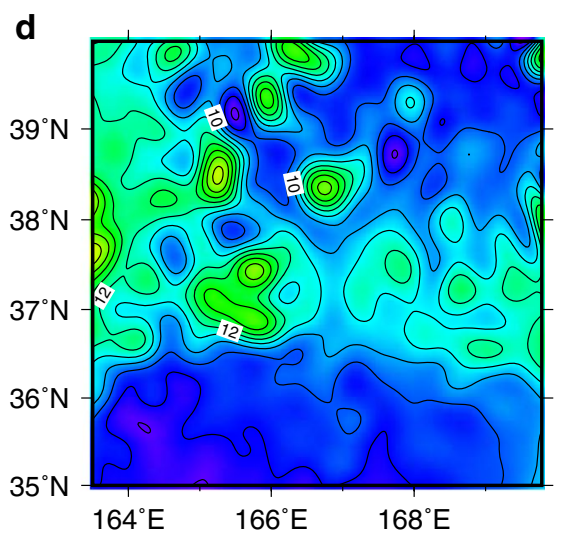

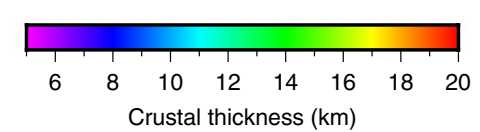

Fig. 3 Crustal thickness results. a RMS misfit between crustal thicknesses by our analysis and by Ohira et al. (2017) for an area of normal oceanic crust (location in Fig. 1a). The dashed line represents the crustal thickness at the RMS minimum. $\mathbf{b}$ Crustal thickness along the survey line of Ohira et al. (2017) as determined by Ohira et al. (2017) (dashed line) and by our calculations using a constant reference crustal thickness of 8.5 km (solid line). c Map of crustal thickness around the survey line of Ohira et al. (2017) calculated for a reference crustal thickness of 8.5 km; contour interval $1 \mathrm{~km}$. The thick white-edged line is the survey line of Ohira et al. (2017); the red portion was used for fitting crustal thickness (see the text). $\mathbf{d}$ Map of crustal thickness in the ORS study area for a reference crustal thickness of $8.5 \mathrm{~km}$; contour interval $1 \mathrm{~km}$

in Fig. 3b, and the crustal thickness variations in the area of the survey line based on the $8.5 \mathrm{~km}$ reference thickness is shown in Fig. 3c. The crust beneath the ORS study area is everywhere thicker than $7 \mathrm{~km}$, reaching $14 \mathrm{~km}$ at $37^{\circ} 25^{\prime} \mathrm{N}, 166^{\circ} 50^{\prime} \mathrm{E}$, and it has a mean thickness of $10.1 \pm 1.7 \mathrm{~km}$ (Fig. 3d). We used this value in Eq. 4 to calculate the theoretical admittances. The mean water depth $d$ and crustal density $\rho_{\mathrm{c}}$ used in this calculation were derived from the slope of a plot of $\log _{10}$ admittance vs wavenumber and its intersection at $k=0$ (Fig. 4a; Watts 2001). The best-fit straight line for an admittance of $0.08<k<0.4 \mathrm{~km}^{-1}$ gave estimates of $d=5838 \mathrm{~m}$ and $\rho_{\mathrm{c}}=2811 \mathrm{~kg} \mathrm{~m}^{-3}$.

The coherence of bathymetry and gravity exceeds the threshold of 0.4 for wavenumbers between 0.04 and $0.22 \mathrm{~km}^{-1}$ (Fig. 4b). The coherence for the wavenumbers greater than $0.4 \mathrm{~km}^{-1}$ is almost zero. We therefore used only the data for the wavenumber band of 0.04 to $0.22 \mathrm{~km}^{-1}$ for the admittance analysis.

Figure 4c compares the observational admittances and the best-fitting admittance model. The $T_{\mathrm{e}}$ value of this model is $2.7 \pm 0.1 \mathrm{~km}$, and the RMS is $4.4 \mathrm{mGal} \mathrm{km}^{-1}$ (Fig. 4d). Watts et al. (2006) showed that seamounts with $T_{\mathrm{e}}$ values less than $8 \mathrm{~km}$ formed on young lithosphere, that is, on or near a spreading ridge. On this basis, we propose that the ORS was formed on or near a spreading ridge.

We determined $T_{\mathrm{e}}$ values for several different cases to confirm the robustness of our analysis. To estimate the influence of the error in crustal thickness, we calculated $T_{\mathrm{e}}$ values for crustal thicknesses between 8.4 and $11.8 \mathrm{~km}$. These ranged from 2.3 to $3.2 \mathrm{~km}$ (Fig. $4 \mathrm{~d}$ ), implying that $T_{\mathrm{e}}$ value is fairly constant within the tolerance interval of crustal thickness. The $T_{\mathrm{e}}$ value for a crustal thickness of 

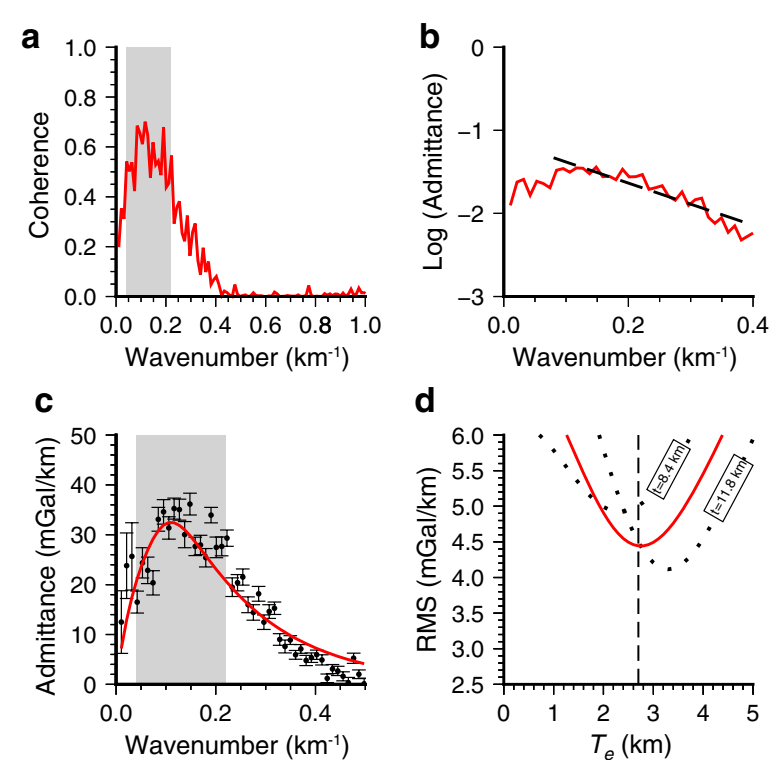

\section{d}

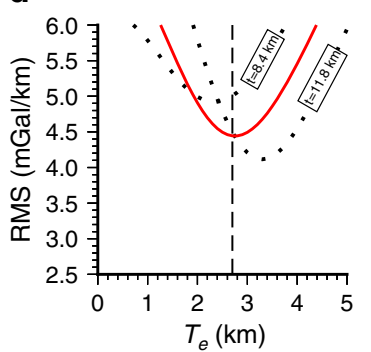

Fig. 4 Results of admittance analysis. a Admittance amplitude vs wavenumber $k$ (red line) with dashed line indicating the best fit to the observed admittance for $0.08<k<0.4$. $\mathbf{b}$ Coherence of the observation admittance values (red line). The gray area is the range of wavenumbers where coherence exceeds the threshold of 0.4. c Observational admittances (black circles with standard deviations) and the theoretical admittance for $T_{e}=2.7 \mathrm{~km}$ (red line). $\mathbf{d}$ RMS misfit between observational and theoretical admittances (red line). The vertical dotted line represents the $T_{\mathrm{e}}$ value at the minimum RMS. Dashed lines represent RMS misfits between observational and theoretical admittances for crustal thicknesses of 8.4 and $11.8 \mathrm{~km}$

$8 \mathrm{~km}$, typical of the normal oceanic crust around Shatsky Rise (e.g., Ohira et al. 2017; Zhang et al. 2016), was $3.6 \pm 0.1 \mathrm{~km}$. Given a window size of $600 \mathrm{~km} \times 600 \mathrm{~km}$, $T_{\mathrm{e}}$ was $2.8 \pm 0.1 \mathrm{~km}$, which is within the error range of $T_{\mathrm{e}}$ value with our $550 \mathrm{~km} \times 550 \mathrm{~km}$ window. In all cases, the $T_{\mathrm{e}}$ values around the ORS were less than $4 \mathrm{~km}$, implying that our analysis is appropriate to address the formation of the ORS.

\section{Discussion}

$T_{\mathrm{e}}$ values less than $8 \mathrm{~km}$ for the underlying lithosphere imply that the seamounts of the ORS formed on a young and weak plate (Watts et al. 2006). Thus, the $T_{\mathrm{e}}$ value of $2.7 \pm 0.1 \mathrm{~km}$ for the seafloor around the ORS indicates that the seamounts formed on or near the spreading ridge between the Pacific and Farallon plates (PacificFarallon ridge). Similarly, with $T_{\mathrm{e}}$ value less than $8 \mathrm{~km}$, the age of the lithosphere at the time of seamount loading is less than 30 Myr (Watts et al. 2006), suggesting that the age of the seafloor in the western (older) margin of the ORS is about 134 Ma (Nakanishi et al. 1999) and that the ORS formed between 104 and $134 \mathrm{Ma}$. Our result is consistent with the $\sim 120-124 \mathrm{Ma}{ }^{40} \mathrm{Ar} /{ }^{39} \mathrm{Ar}$ ages of the seamounts on top of the ridge (Sano et al. 2016; around $36^{\circ} 45^{\prime} \mathrm{N}$ and $166^{\circ} 00^{\prime} \mathrm{E}$ ).

Tejada et al. (2016) raised the possibility that the ORS was formed by late-stage volcanism of Shatsky Rise and is a hotspot track representing the "plume head to tail" stage of hotspot development. The plate reconstruction model of Torsvik et al. (2019) also suggests that the ORS represents the track of the hotspot that formed Shatsky Rise from 135 to $\sim 120 \mathrm{Ma}$. This age range is close to that of the seafloor around the ORS determined from magnetic anomaly lineations (125-134 Ma) and the radiometric ages of the seamounts. These lines of evidence support our inference that the ORS was formed on or near the Pacific-Farallon ridge.

The mean crustal thickness beneath the ORS is $10.1 \pm 1.7 \mathrm{~km}$, which is $\sim 3 \mathrm{~km}$ thicker than that of the oceanic crust around Shatsky Rise. Some of the Foundation Seamounts near the East Pacific Rise, which are similar to the ORS in topography, size, and shape, are parallel or subparallel to the Pacific-Antarctic Ridge (O'Connor et al. 2004). The Foundation Seamounts, which were formed by the interaction between a spreading ridge and a hotspot (Maia and Arkani-Hamed 2002; O'Connor et al. 2001), have $T_{\mathrm{e}}$ values of 0-5 km (Maia and ArkaniHamed 2002), and the crust beneath them is $6 \mathrm{~km}$ thicker than the surrounding normal oceanic crust (Maia et al. 2000). These similarities between the ORS and Foundation Seamounts suggest that they were formed by the same mechanism. Thus, we conclude that the ORS was formed by the interaction between the Pacific-Farallon ridge and the hotspot forming Shatsky Rise, consistent with the model proposed by Tejada et al. (2016). The ORS does not show a clear hotspot track like the HawaiianEmperor volcanic chain, perhaps because interactions with the spreading ridge produced scattered near-ridge volcanoes and led to a diffuse hotspot track.

Tejada et al. (2016) proposed that the volcanic edifices on and around Shatsky Rise, such as Toronto Ridge and Cooperation Seamount, formed by late-stage volcanism related to the formation of Shatsky Rise that took place far from plate boundaries (Fig. 1a). The ages of Toronto Ridge and Cooperation Seamount, 129.4 $\pm 0.3 \mathrm{Ma}$ and $\sim 122 \mathrm{Ma}$, respectively (Tejada et al. 2016), are close to the age of the ORS estimated by our study. Several other volcanic cones on Shatsky Rise are also thought to have formed by late-stage volcanism (Zhang et al. 2017). Ohira et al. (2017) proposed late-stage volcanism beneath the abyssal basin southeast of Shatsky Rise to explain the thick crust-mantle transition layer there. These studies as well as our results indicate that late-stage volcanism related to the formation of Shatsky Rise not only occurred within the rise itself, but also extended to the abyssal basin to the east. Our results also indicate that 
the late-stage hotspot volcanism occurred not only within the Pacific plate, but also near a plate boundary, the Pacific-Farallon ridge.

\section{Conclusions}

Our analysis of bathymetric and gravity data provides new insight into the tectonic setting of the ORS, east of Shatsky Rise. Our study indicates that the effective elastic thickness of the lithosphere and the mean thickness of the crust beneath the ORS are $2.7 \pm 0.1 \mathrm{~km}$ and $10.1 \pm 1.7 \mathrm{~km}$, respectively. The small effective elastic thickness suggests that the ORS formed on or near the Pacific-Farallon ridge, and the thick crust indicates that the ORS formed by the interaction between the PacificFarallon ridge and the hotspot forming Shatsky Rise. The volcanism forming the ORS was part of the late-stage volcanism associated with Shatsky Rise, which occurred on or near a spreading ridge. This late-stage volcanism extended beyond the rise itself to the abyssal basin to the east. Our conclusion should be tested by further sampling from the wide area of the ORS.

\author{
Abbreviations \\ FGA: Free-air gravity anomaly; MBA: Mantle Bouguer anomaly; ORS: Ojin Rise \\ Seamounts; RMS: Root-mean-square; $T_{\mathrm{e}}$ : Effective elastic thickness.
}

\section{Acknowledgements}

We thank the crew and technical staff of cruise KR14-07 for collection of the geophysical data used in this study and M.L.G. Tejada for discussion and comments on this manuscript. We are grateful for the constructive reviews of the editor and two anonymous reviewers that significantly improved this manuscript. Funding was provided by the Japan Society for the Promotion of Science under KAKENHI Grants no. 26302010, 18H03746, and 18 K03772.

\section{Authors' contributions}

The KR14-07 cruise was planned by TS and MN. Analyses were performed by SS and MN, and the manuscript was written by SS with extensive input and discussion from MN and TS. All authors read and approved the final manuscript.

\section{Funding}

Funding was provided by the Japan Society for the Promotion of Science under KAKENHI Grants no. 26302010, 18H03746, and 18K03772.

\section{Availability of data and materials}

The bathymetric dataset of cruise KR14-07 is available in the Data and Sample Research System of the Japan Agency for Marine-Earth Science and Technology, http://www.godac.jamstec.go.jp/darwin/e.

\section{Ethics approval and consent to participate}

Not applicable.

\section{Consent for publication \\ Not applicable.}

\section{Competing interests}

The authors declare that they have no competing interests.

\section{Author details}

${ }^{1}$ Graduate School of Science and Engineering, Chiba University,

Chiba 2638522, Japan. ${ }^{2}$ Graduate School of Science, Chiba University,
Chiba 2638522, Japan. ${ }^{3}$ Department of Geology and Paleontology, National Museum of Nature and Science, Ibaraki 3050005, Japan.

Received: 3 October 2019 Accepted: 20 January 2020

Published online: 03 February 2020

\section{References}

Clague DA, Dalrymple GB (1987) The Hawaiian-Emperor volcanic chain. Part I. Geologic evolution. In: Decker RW, Wright TL, Stauffer PH (eds) Volcanism in Hawaii. US Geol Sur Prof Paper 1350. Reston, U.S. Geological Survey, pp 5-54

Duncan RA, Richards MA (1991) Hotspots, mantle plumes, flood basalts, and true polar wander. Rev Geophys 29(1):31-50. https://doi. org/10.1029/90RG02372

Geldmacher J, van den Bogaard P, Heydolph K, Hoernle K (2014) The age of Earth's largest volcano: Tamu Massif on Shatsky Rise (northwest Pacific Ocean). Int J Earth Sci 103(8):2351-2357. https://doi.org/10.1007/s0053 1-014-1078-6

Heaton DE, Koppers AAP (2014) Constraining the rapid construction of Tamu Massif at an 145 Myr old triple junction, Shatsky Rise. In: Goldschmidt conference, Sacramento, California, 8-13 June 2014

Hu M, Li J, Jin T, Xu X, Xing L, Shen C, Li H (2015) Three-dimensional estimate of the lithospheric effective elastic thickness of the Line ridge. Tectonophysics 658:61-73. https://doi.org/10.1016/j.tecto.2015.07.008

Ito G, Clift PD (1998) Subsidence and growth of Pacific Cretaceous plateaus. Earth Planet Sci Lett 161(1-4):85-100. https://doi.org/10.1016/S0012 $-821 \times(98) 00139-3$

Kalnins LM, Watts AB (2009) Spatial variations in effective elastic thickness in the Western Pacific Ocean and their implications for Mesozoic volcanism. Earth Planet Sci Lett 286(1-2):89-100. https://doi.org/10.1016/j. epsl.2009.06.018

Korenaga J, Sager WW (2012) Seismic tomography of Shatsky Rise by adaptive importance sampling. J Geophys Res. https://doi.org/10.1029/2012j b009248

Kuo BY, Forsyth DW (1988) Gravity anomalies of the ridge-transform system in the South Atlantic between $31^{\circ}$ and $34.5^{\circ} \mathrm{S}$ : upwelling centers and variations in crustal thickness. Mar Geophys Res 10(3-4):205-232. https://doi. org/10.1007/bf00310065

Mahoney JJ, Duncan RA, Tejada MLG, Sager WW, Bralower TJ (2005) JurassicCretaceous boundary age and mid-ocean-ridge-type mantle source for Shatsky Rise. Geology 33(3):185-188. https://doi.org/10.1130/G21378.1

Maia M, Arkani-Hamed J (2002) The support mechanism of the young Foundation Seamounts inferred from bathymetry and gravity. Geophys J Int 149(1):190-210. https://doi.org/10.1046/j.1365-246X.2002.01635.x

Maia M, Ackermand D, Dehghani GA, Gente P, Hékinian R, Naar D, O'Connor J, Perrot K, Morgan P, Ramillien G, Révillon S, Sabetian A, Sandwell DT, Stoffers $P$ (2000) The Pacific-Antarctic Ridge-Foundation hotspot interaction: a case study of a ridge approaching a hotspot. Mar Geol 167(1-2):61-84. https://doi.org/10.1016/S0025-3227(00)00023-2

McKenzie D, Bowin C (1976) The relationship between bathymetry and gravity in the Atlantic Ocean. J Geophys Res 81(11):1903-1915. https://doi. org/10.1029/JB081i011p01903

Nakanishi M, Sager WW, Klaus A (1999) Magnetic lineations within Shatsky Rise, northwest Pacific Ocean: implications for hot spot triple junction interaction and oceanic plateau formation. J Geophys Res 104(B4):75397556. https://doi.org/10.1029/1999JB900002

O'Connor JM, Stoffers P, Wijbrans JR (2001) En echelon volcanic elongate ridges connecting intraplate Foundation Chain volcanism to the PacificAntarctic spreading center. Earth Planet Sci Lett 192(4):633-648. https:// doi.org/10.1016/S0012-821X(01)00461-7

O'Connor JM, Stoffers P, Wijbrans JR (2004) The foundation chain: inferring hotspot-plate interaction from a weak seamount trail. In: Hekinian R, Cheminée JL, Stoffers P (eds) Oceanic hotspots. Springer, Berlin, pp 349-374. https://doi.org/10.1007/978-3-642-18782-7_12

Ohira A, Kodaira S, Nakamura Y, Fujie G, Arai R, Miura S (2017) Structural variation of the oceanic Moho in the Pacific plate revealed by active-source seismic data. Earth Planet Sci Lett 476:111-121. https://doi.org/10.1016/j. epsl.2017.08.004 
Pietsch R, Uenzelmann-Neben G (2015) The Manihiki Plateau-a multistage volcanic emplacement history. Geochem Geophys Geosyst 16(8):24802498. https://doi.org/10.1002/2015GC005852

Sager WW, Kim J, Klaus A, Nakanishi M, Khankishieva LM (1999) Bathymetry of Shatsky Rise, northwest Pacific Ocean: implications for ocean plateau development at a triple junction. J Geophys Res 104(B4):7557-7576. https://doi.org/10.1029/1998JB900009

Sager WW, Sano T, Geldmacher J (2016) Formation and evolution of Shatsky Rise oceanic plateau: insights from IODP Expedition 324 and recent geophysical cruises. Earth Sci Rev 159:306-336. https://doi.org/10.1016/j. earscirev.2016.05.011

Sandwell DT, Müller RD, Smith WHF, Garcia E, Francis E (2014) New global marine gravity model from CryoSat-2 and Jason- 1 reveals buried tectonic structure. Science 346(6205):65-67. https://doi.org/10.1126/scien ce. 1258213

Sano T (2014) R/V KAIREI "Cruise Report" KR14-07, Japan Agency for MarineEarth Science and Technology. http://www.godac.jamstec.go.jp/catalog/ doc_catalog/metadataDisp/KR14-07_all?lang=en. Accessed 30 Aug 2019

Sano T, Shimizu K, Ishikawa A, Senda R, Chang Q, Kimura Jl, Widdowson M, Sager WW (2012) Variety and origin of magmas on Shatsky Rise, northwest Pacific Ocean. Geochem Geophys Geosyst. https://doi. org/10.1029/2012gc004235

Sano T, Hanyu T, Tejada MLG, Shimizu S, Nakanishi M, Koppers AAP, Kumagai I, Geldmacher J, Sager WW (2016) Magma genesis of Ojin Rise Seamounts, Northeast of Shatsky Rise. In: AGU fall meeting, San Francisco, California, 12-16 December 2016

Shimizu K, Shimizu N, Sano T, Matsubara N, Sager WW (2013) Paleo-elevation and subsidence of $\sim 145 \mathrm{Ma}$ Shatsky Rise inferred from $\mathrm{CO}_{2}$ and $\mathrm{H}_{2} \mathrm{O}$ in fresh volcanic glass. Earth Planet Sci Lett 383:37-44. https://doi. org/10.1016/j.epsl.2013.09.023

Smith WHF, Sandwell DT (1997) Global seafloor topography from satellite altimetry and ship depth soundings. Science 277:1957-1962. https://doi. org/10.1126/science.277.5334.1956

Smith WHF, Wessel P (1990) Gridding with continuous curvature splines in tension. Geophysics 55:293-305. https://doi.org/10.1190/1.1442837

Straume EO, Gaina C, Medvedev S, Hochmuth K, Gohl K, Whittaker JM, Abdul Fattah R, Doornenba JC, Hopper JR (2019) GlobSed: updated total sediment thickness in the world's oceans. Geochem Geophys Geosyst 20(4):1756-1772. https://doi.org/10.1029/2018GC008115
Tejada MLG, Shimizu K, Suzuki K, Hanyu T, Sano T, Nakanishi M, Nakai S, Ishikawa A, Chang Q, Miyazaki T, Hirahara Y, Takahashi T, Senda R (2015) Isotopic evidence for a link between the Lyra Basin and Ontong Java Plateau. In: Neal CR, Sager WW, Sano T, Erba E (eds) The origin, evolution, and environmental impact of oceanic large igneous provinces, vol 511. Special Paper of the Geological Society of America. Geological Society of America, Boulder, pp 251-269. https://doi.org/10.1130/2015.2511(14)

Tejada MLG, Geldmacher J, Hauff F, Heaton D, Koppers AA, Garbe-Schönberg D, Hoernle K, Sager WW (2016) Geochemistry and age of Shatsky, Hess, and Ojin Rise seamounts: implications for a connection between the Shatsky and Hess Rises. Geochim Cosmochim Acta 185:302-327. https:// doi.org/10.1016/j.gca.2016.04.006

Torsvik TH, Steinberger B, Shephard GE, Doubrovine PV, Gaina C, Domeier M, Sager WW (2019) Pacific-Panthalassic reconstructions: overview, errata and the way forward. Geochem Geophys Geosyst. https://doi. org/10.1029/2019GC008402

Walcott RI (1976) Lithospheric flexure, analysis of gravity anomalies, and the propagation of seamount chains. Geophys Pac Ocean Basin Margin 19:431-438. https://doi.org/10.1029/GM019p0431

Watts AB (1978) An analysis of isostasy in the world's oceans 1. HawaiianEmperor Seamount Chain. J Geophys Res 83(B12):5989-6004. https://doi. org/10.1029/JB083iB12p05989

Watts AB (2001) Isostasy and flexure of the lithosphere. Cambridge University Press, Cambridge

Watts AB, Sandwell DT, Smith WHF, Wessel P (2006) Global gravity, bathymetry, and the distribution of submarine volcanism through space and time. J Geophys Res. https://doi.org/10.1029/2005jb004083

Zhang J, Sager WW, Korenaga J (2016) The seismic Moho structure of Shatsky Rise oceanic plateau, northwest Pacific Ocean. Earth Planet Sci Lett 441:143-154. https://doi.org/10.1016/j.epsl.2016.02.042

Zhang J, Sager WW, Durkin WJ (2017) Morphology of Shatsky Rise oceanic plateau from high resolution bathymetry. Mar Geophys Res 38(1-2):169185. https://doi.org/10.1007/s11001-016-9272-5

\section{Publisher's Note}

Springer Nature remains neutral with regard to jurisdictional claims in published maps and institutional affiliations.

\section{Submit your manuscript to a SpringerOpen ${ }^{\circ}$ journal and benefit from:}

- Convenient online submission

- Rigorous peer review

- Open access: articles freely available online

- High visibility within the field

- Retaining the copyright to your article

Submit your next manuscript at $\boldsymbol{\nabla}$ springeropen.com 